\section{British report real decline in spending on research}

London. British spending on research and development declined in value between 1989 and 1990, according to the government's annual review of research spending in the $£ 28.00$ ). The two years are the most recent for which figures are available.

The decline in real spending from $£ 9.239$ billion to £9.187 billion (measured in 1985 prices) chiefly reflects a decline in the gov-

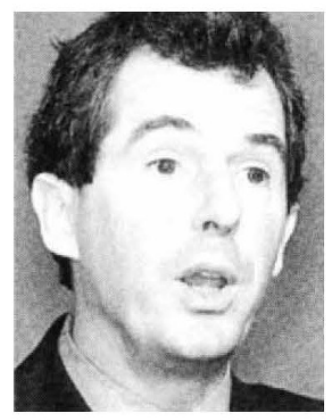

William Waldegrave spending on research. There has been a steady decline in the real cost of defence research and development, which peaked (in cash terms) in 1985 , and which has declined in every subsequent year except 1989 ernment's own (which explains the recorded drop between 1989 and 1990). More worrying is what seems to be a stagnation of industrial spending on intramural research, which seems to have settled at 1.5 per cent of gross domestic product (GDP) since 1986 (when it amounted to 1.6 per cent of GDP).

One curious feature of the statistics now published is that while the government's contribution to industrial research spending has declined from 30 per cent in 1967 to 17 per cent in 1990, industry's own share of the cost has remained at about 68 per cent. The difference is made up by the category 'overseas', including such sources as the European Commission and defence contracts with overseas organizations. fence research establishments. United Kingdom ( $R \& D$ 1992, HMSO

The annual review's comparison of British research spending with that overseas is again unflattering. The British share of GDP spent on civil science declined from 0.63 per cent in 1985 to 0.51 per cent in 1990 . Of the G-7 states (with Sweden replacing Canada) cited in the annual review, only Japan (notoriously mean with government grants) and the United States spent a smaller proportion of GDP on civil science $(0.43$ per cent and 0.44 per cent respectively in 1990).

The decline of spending on research and development seems to have been matched by a decline of employment on these functions. The annual review says that the number of technical people employed by government has shrunk steadily from 57,000 in 1983 to an estimated 35,000 in the current year. A further 1,500 government scientists are expected to be lost in the next two years, mostly from the research councils and de-

Industrial employment has done little to take up the slack, although the number of scientists and engineers had grown from 77,000 to 85,000 in 1989 before falling by 5,000 in the following year. Support staffs, especially technicians, have fallen sharply over the period, with the result that total technical employment in industry fell from 185,000 in 1983 to 165,000 in 1990 .

In the nature of annual reviews (this was required in 1981 by the House of Lords Select Committee on Science and Technology), the text offers little in the way of promises. But on this occasion, the introductory pages draw attention to the appointment of William Waldegrave as the first minister of science in Britain for 30 years. The text comes as close as it could to offering the prospect that things will be different without promising that they will be. John Maddox

\section{Japan prepares spending increase}

Tokyo. An advisory body to the Japanese Ministry of Education, Science and Culture last week recommended that the budget for competitive research grants for university researchers should be raised "at an early stage" by 50 per cent, to $¥ 100$ billion (US $\$ 800$ million) a year.

The Japanese cabinet is expected to welcome the suggestion: earlier this year, it announced its intention to double government spending on research to 1 per cent of the country's gross national product (GNP). The move should provide a significant boost in funds for Japan's cash-starved university researchers.

The ministry's competitive research grant budget, which stands at $¥ 64.6$ billion, has been growing in recent years at an annual rate of 5-10 per cent, well above inflation. Even so, researchers complain that many worthwhile research proposals are rejected because of insufficient funds. At the same time, the ministry has held down the budget for the fixed maintenance grants of a few million yen that go automatically to each university research department as part of its policy to reward centres of research excellence. The new recommendation conforms to the ministry's efforts to put a larger portion of the research grants budget on a competitive basis.

David Swinbanks

\section{Wellcome Trust to double spending after sale of shares}

London. The Wellcome Trust plans to double its spending on medical research next year after receiving $£ 2.16$ billion (US $\$ 4.1$ billion) from the sale of part of its holdings in the pharmaceutical company Wellcome PLC. The sale, completed last Monday, 27 July, will enable the charity to become the largest single source of medical research funding in Britain.

Officials of the trust have begun meetings with other interested parties on how to allocate that additional money. The sale will double the medical charity's spending on research from $£ 110$ million this year to $£ 220$ million in 1993-94.

In 1986, the charity sold a quarter of the company's stock; since then, the success of the AIDS drug AZT has boosted the share price considerably. The current sale of around 30 per cent of the company's stock still leaves the trust holding 42 per cent. The money from the sale will be reinvested in higher-yielding stocks, with some of the increased dividends spent on research.

The consultations - with government, the Medical Research Council (MRC), medical schools and universities, and the Association of Medical Research Charities - are intended to identify priorities and ensure that the funding from each of these bodies remains complementary. Although no details have been announced, the Wellcome Trust's director, Bridget Ogilvie, has spoken of the need for capital equipment and new buildings. Large projects are currently under way at the Royal Postgraduate Medical School and University College, London.

Last week, the trust confirmed that it would spend $£ 50$ million in the next five years on a genetic research centre that will, among other things, house John Sulston's team working on Caenorhabditis elegans (see Nature 357, 99; 1992). A site for the new centre, named after Cambridge biochemist Frederick Sanger and funded jointly with the MRC, has not been chosen.

Ogilvie also said that the trust is concerned about the insecure conditions under which researchers are employed. "Too many scientists are on 'soft money', short-term contracts without any certainty of renewal", she says. "This must be wrong."

Working parties will be set up to review the trust's funding of equipment in universities and to find ways to increase its longstanding commitment to tropical medicine, both indigenous diseases and those in which expression differs according to environment. The trust is also interested in bolstering such areas as the training of clinicians in research, psychiatry and research into vision, veterinary medicine, mathematical biology and taxonomy.

Ian Mundell 